\title{
The impacts of land use changes in the mercury flux in the Madeira River, Western Amazon
}

\author{
LUIZ D. LACERDA ${ }^{1}$, WANDERLEY R. BASTOS ${ }^{2}$ and MARCELO D. ALMEIDA ${ }^{1}$ \\ ${ }^{1}$ Instituto de Ciências do Mar, Universidade Federal do Ceará, \\ Av. Abolição, 3207, 60165-081 Fortaleza, CE, Brasil \\ ${ }^{2}$ Laboratório de Biogeoquímica Ambiental, Núcleos de Saúde, Ciência e Tecnologia, \\ Universidade Federal de Rondônia, Rodovia BR-364, km 9.5, 78900-500 Porto Velho, RO, Brasil \\ Manuscript received on October 28, 2010; accepted for publication on September 28, 2011
}

\begin{abstract}
Changes in hydrochemistry and $\mathrm{Hg}$ distribution in the Madeira River from Porto Velho to the confluence with the Amazon River were studied in two cruises in 1997 and 2002. Water conductivity was similar in both periods, but the $\mathrm{pH}$ was significantly higher in 2002, in particular along the middle reaches of the river. Total suspended matter concentrations also increased from 1997 to 2002 along the same river portion, which is a result of forest conversion to other land uses, in particular pastures and agriculture accelerated during the interval between the cruises. Dissolved Hg concentrations were similar along the river in both cruises, but particulate $\mathrm{Hg}$ concentrations increased significantly along the middle portion of the river, although the suspended matter from 2002 was relatively poorer in $\mathrm{Hg}$ compared to that from 1997. Since particulate $\mathrm{Hg}$ represents more than $90 \%$ of the total $\mathrm{Hg}$ present in the river water, there was a significant increase in the total $\mathrm{Hg}$ transport in the Madeira River. Although gold mining has nearly ceased to exist in the region, the remobilization of $\mathrm{Hg}$ from forest soils through conversion to other land uses is responsible for maintaining relatively high $\mathrm{Hg}$ content in the Madeira River environment.
\end{abstract}

Key words: deforestation, Mercury, hydrochemistry, contamination, Amazon.

\section{INTRODUCTION}

The production of gold in the Amazon relies on the $\mathrm{Hg}$ amalgamation to separate fine gold particles from riverbank deposits and bottom sediments. This simple, cheap and reliable technique produced about 2,000 tons of gold from 1975 to 2002, leaving behind nearly 3,000 tons of $\mathrm{Hg}$ in the region's environment (Lacerda 2003). The Madeira River Basin was the second most important gold

Correspondence to: Luiz Drude de Lacerda

E-mail:1drude@pq.cnpq.br mining area in the Amazon. Starting in 1975 as an individual operation along riverbanks and fluvial islands during the dry season, the activity reached its maximum in the late 1980's, when over 1,500 dredges were working directly on the river bottom along a $300 \mathrm{~km}$ stretch of the Madeira River, from Porto Velho to the Bolivian border at Guajará Mirin (Figure 1). During this period, about 9.4 t.yr $^{-1}$ of gold were produced, with an estimated release of 12.4 t.yr $^{-1}$ of Hg. Between 1979 and 1988, about $87 \mathrm{t}$ of $\mathrm{Hg}$ were emitted to the regional environment, 
$65 \%$ to the atmosphere through amalgam burning and bullion smelting, and $45 \%$ discharged directly into rivers as metallic $\mathrm{Hg}$ during the mining operation (Pfeiffer and Lacerda 1988, Lacerda et al. 1989). Since 1995, the gold extraction returned to an individual level and gold production dropped from about 0.3 to $0.5 \mathrm{t}_{\text {. }} \mathrm{yr}^{-1}$.

Most of the $\mathrm{Hg}$ emitted to the atmosphere during these 30 years was deposited within about $40 \mathrm{~km}$ from the source, i.e. in forest soils along the river (Lacerda et al. 2004). Also, gold extraction continued and even increased in the Bolivian part of the basin, and the $\mathrm{Hg}$ released to the atmosphere eventually returned to the basin soils (Maurice-Bourgoin et al. 2000). The basin soils, therefore, act as a temporary sink, and the $\mathrm{Hg}$ release to waterways is no longer just a function of the emissions, but also of land use changes, which may trigger transformations and interactions with other environmental compartments that eventually remobilize $\mathrm{Hg}$ to food chains and increase its bioavailability through methylation. As for the riverside populations, fish is their main protein source, with a daily consumption of up to $500 \mathrm{~g}$. Therefore, even relatively small increases of $\mathrm{Hg}$ concentrations in fish due to the increasing bioavailability may result in high exposure doses for these human groups (Boischio and Henshel 2000, Roulet et al. 2000).

Notwithstanding the decreasing of direct emissions, $\mathrm{Hg}$ contamination observed in some aquatic and human populations, still threatens the region, posing a permanent environmental concern to local and national environmental and health authorities and, in the absence of significant direct $\mathrm{Hg}$ sources, may be a response to land use changes intensified in the past two decades in the region (Bastos et al. 2006). Ferraz et al. (2005) made a thoroughly assessment of possible future scenarios for land use changes in Rondônia. According to their study, the most rapid rates of deforestation in Rondônia occurred in 1984-1986, 1988-1990, 1994-1996 and 2000-2002. In 2002 Central
Rondônia was less than $25 \%$ forested and was at a final and critical stage of deforestation. In this context the mature forest should be reduced to $5 \%$ of the area by 2015 . With decreasing primary forests, new areas for pasture or agriculture and small ranch operations tend to be agglomerated into large ranch operations, which have better economical conditions to invest in equipment and inputs in order to sustain productivity. Therefore, effects on rivers could worsen due to the lack of riparian vegetation and drastic reduction of forest areas, increasing soil denudation and runoff, affecting water quality, flood regime and increasing soil $\mathrm{Hg}$ transfer to rivers. To test the effects of land use changes on the $\mathrm{Hg}$ remobilization we compared $\mathrm{Hg}$ concentrations and fluxes along the Madeira River between Porto Velho (Rondônia State) and its mouth at the Amazon River close to Itacoatiara (Amazonas State) (Figure 1) based on samples collected in two cruises in 1997, just after the cessation of large scale gold extraction in the river, and in 2002, when most land conversion in the basin has occurred.

\section{MATERIALS AND METHODS}

The Madeira River is the most important southern tributary of the Amazon River. It has $1,459 \mathrm{~km}$ in length and is placed totally inside the Brazilian territory, running through Rondônia and Amazon States (Figure 1). The river has an average flow of $31,200 \mathrm{~m}^{3} \cdot \mathrm{s}^{-1}$ (5,000 to $\left.45,000 \mathrm{~m}^{3} \cdot \mathrm{s}^{-1}\right)$, being the twentieth largest river in the world. The Madeira River Basin drains an area of $1,420,000 \mathrm{~km}^{2}$, divided into two different sections. The upper Madeira River is located between the confluence of the Mamoré and Beni rivers until Porto Velho and has about $360 \mathrm{~km}$ in length. The lower Madeira River, our study area, is located between Porto Velho, RO and Itacoatiara, AM. With a navigable extension of $1,100 \mathrm{~km}$, it is the most important waterway of South America, (Silveira et al. 2000). The river 

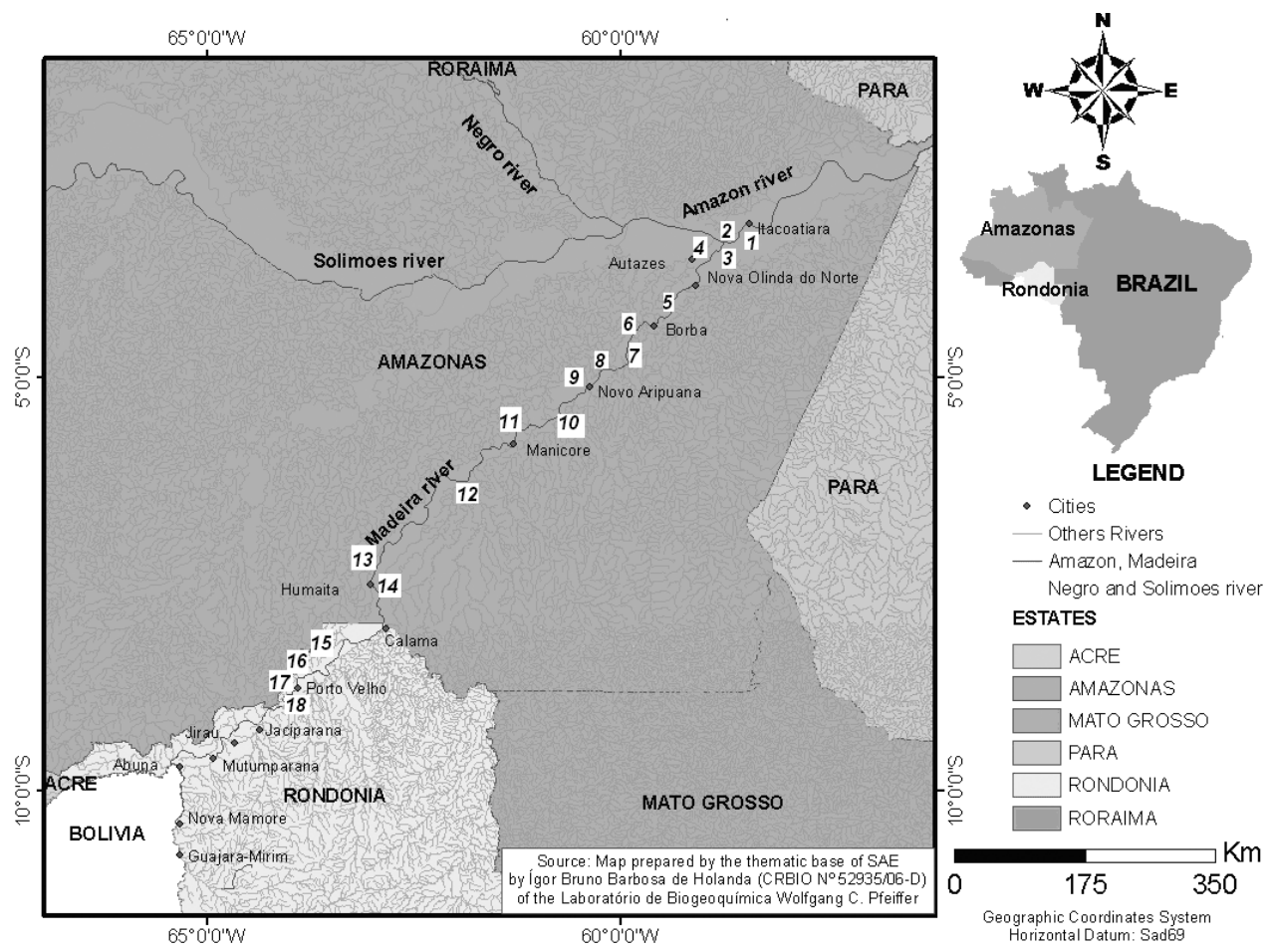

Figure 1. Location of the sampling area along the Madeira River from Porto Velho to the confluence with the Amazon River.

is classified as a white-yellowish-water river, rich in dissolved material and suspended solids. The estimated total material transport reaches

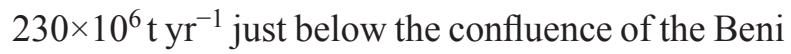
and Mamoré Rivers, which form the Madeira River (Guyot et al. 1999). Further downstream, from Porto Velho to the Amazon, the suspended sediment load varies from 37-40 x $10^{6}$ t.yr $^{-1}$, but can reach $14 \times 10^{8}$ t. $\mathrm{yr}^{-1}$ during the rainy season. The basin soils include latossols, argissols, neossols, gleissols and cambissols, but latosols dominate about $60 \%$ of the area (Mortatti et al. 1989).

Surface water, suspended solids and river bottom sediments samples were collected from two cruises in May 1997 and 2002 from Itacoatiara, in the Amazon River, just downstream of the Madeira River mouth, to Porto Velho, about 1,100 $\mathrm{km}$ upriver. Sampling stations were established at about $150 \mathrm{~km}$ intervals and downstream of major tributaries of the southern margin of the Madeira River (Figure 1). At each sampling station major hydrochemical variables (temperature, $\mathrm{pH}$ and electric conductivity) were monitored during the sampling period. Suspended solids and bottom sediments were collected in sedimentation areas of the Madeira River. In three additional expeditions in 2004 and 2005, 186 soil samples representing different soil types and soil uses were collected along the entire stretch of the river in 42 stations located within $500 \mathrm{~m}$ from the river margins (Figure 1).

Water samples were vacuum-filtrated through previously acid washed cellulose membranes ( $0.45 \mu \mathrm{m}$ of pore diameter) from 5 liters polyethylene bottles. During filtration, $250 \mathrm{ml}$ subsamples were taken for the determination of dissolved $\mathrm{Hg}$ using acid-clean PET bottles. Field blanks were obtained at one in each of three stations by filtering bi-distilled water through the same filtering systems. Subsamples of suspended matter retained in filters of about $0.5 \mathrm{~g}$ were separated for $\mathrm{Hg}$ analysis. Water flasks and filters were double bagged in polyethylene and kept 
cold $\left(<5^{\circ} \mathrm{C}\right)$ for transport. Bottom sediments were collected with an Eckman dredge whereas soils were collected by hand using plastic shovels. Samples were packed in plastic bags, identified and stored under refrigeration $\left(<5^{\circ} \mathrm{C}\right)$. In the laboratory, sediments and soil samples were dried to constant weight at $60^{\circ} \mathrm{C}$. Bottom sediments and soil samples were sieved (74 $\mu \mathrm{m}$ and $2.0 \mathrm{~mm}$, respectively) prior to analysis.

Dissolved $\mathrm{Hg}$ was determined in filtered samples after oxidation with $\mathrm{BrCl}$ at room temperature, when ascorbic acid solution was used to reduce the excess $\mathrm{BrCl}$. This was followed by a reduction with $10 \% \mathrm{SnCl}_{2}$ (Marins et al. 2002). Analysis was performed by atomic florescence spectrophotometry in a Tekran 2500 AFS.

Total $\mathrm{Hg}$ concentrations in soils, suspended solids and bottom sediments were quantified by atomic absorption spectrophotometer coupled with cold vapor generation and flow injection analysis in a Perkin Elmer Flow Injection Mercury system - FIMS 400. The analytical control was accompanied by the analysis of reagent blanks and reference certified samples (IAEA-356 and IAEA405). Average recovery of reference standards was 97\% (Bastos et al. 2006).

\section{RESULTS AND DISCUSSION}

Total $\mathrm{Hg}$ concentrations in soils are presented in table I. Two major dry upland soil types were identified in all sampling stations, argisols and latossols; although other categories of flooded and fluvial soils were present, they were not analyzed in this study. There was no significant difference between both soil types sampled. However, significant differences $(\mathrm{P}<0.01)$ were observed when soils under different uses were compared. Soils under anthropogenic influences (pasture, deforested and secondary growth) were in general less acidic, with lower content of organic matter, $\mathrm{Fe}$ and Al. Mercury concentrations were strikingly different between natural and anthropogenic soils, with the former presenting $\mathrm{Hg}$ concentrations 2-3 times higher. Based on a few cores dug in selected typical spots and considering the first $60 \mathrm{~cm}$ of soil layer, where most denudation processes occur, $\mathrm{Hg}$ content of pasture soils reached $76 \mathrm{mg} \cdot \mathrm{m}^{-2}$, followed by secondary growth $\left(86 \mathrm{mg} \cdot \mathrm{m}^{-2}\right)$ and primary forest $\left(112 \mathrm{mg} \cdot \mathrm{m}^{-2}\right)$. These results suggest that large quantities of $\mathrm{Hg}$ are presently being remobilized from forest soils when converted to other soil uses.

Similar results were found in previous studies on $\mathrm{Hg}$ soil content in the Amazon (Lacerda et al. 2004, Almeida et al. 2005, Bastos et al. 2006, Magarelli and Forstier 2005). Most of these agree that only a small fraction (generally less than 10\%) of this loss is to the atmosphere, and that the major $\mathrm{Hg}$ loss is through erosion and transport through watersheds (Roulet et al. 2000, Lacerda et al. 2004, Almeida et al. 2005, Forstier et al. 2000). For example, Roulet et al. (1999, 2000) suggested that deforestation was responsible for increasing Hg transport through the Tapajós River in Eastern Amazon associated with higher particle loads to the river. Fostier et al. (2000) estimated a doubling of $\mathrm{Hg}$ loss to rivers associated with higher erosion rates after the forest conversion to pasture in an Amapa State watershed, Northern Amazon. Godoy et al. (2002) and Cordeiro et al. (2002), reported an increased $\mathrm{Hg}$ flux to lake sediments in the Pantanal and Alta Floresta, Southern Amazon, associated with increasing soil erosion due to agriculture and road construction, respectively. Similarly, Forsberg et al. (1999) reported that siltation in floodplain lakes increased from $50 \mathrm{mg} \cdot \mathrm{cm}^{-2} \cdot \mathrm{yr}^{-1}$ to $800 \mathrm{mg} \cdot \mathrm{cm}^{-2} \cdot \mathrm{yr}^{-1}$ due to forest conversion to agriculture in a sub-basin of the Madeira River.

The primary vector responsible for increasing $\mathrm{Hg}$ mobilization is the conversion of forest to pasture and agriculture by slash and burning, which results in $\mathrm{Hg}$ degassing to the atmosphere and increasing particulate $\mathrm{Hg}$ transport due to erosion. Deforestation increases soil exposure to extreme climate conditions, allowing the direct 
incidence of solar radiation, including the stronger photo-reducing UV radiation, and augmenting temperatures of the overlying air and the soil itself (Almeida et al. 2009). It also enhances weathering and accelerates changes in the soil composition by increasing $\mathrm{pH}$ and decreasing soil organic matter content and, consequently, the soil capacity to complex and immobilize $\mathrm{Hg}$ by means of organic complexing (Herpin et al. 2002, Moraes et al. 1996). In summary, deforestation increases erosion and mobilization of $\mathrm{Hg}$ and other soil constituents, as well as accelerates $\mathrm{Hg}$ degassing. Therefore, it is probable that the river chemistry and $\mathrm{Hg}$ content in the receiving fluvial system would show the impacts of soil conversion (Lodenius et al. 1987, Schlüer 1997, Roulet et al. 1999, 2000, Amirbahaman et al. 2004, Almeida et al. 2005).

Hydrochemistry and $\mathrm{Hg}$ concentrations and distribution in the waters of the Madeira River observed during the two cruises in 1997 and 2002, from Porto Velho to the confluence with the Amazon River (Figure 1), showed measurable differences between both periods. The water electrical conductivity increased from about $50 \mu \mathrm{S} . \mathrm{cm}^{-1}$ at the confluence with the Amazon River to $130 \mu{\mathrm{S} . \mathrm{cm}^{-1}}^{-1}$ in upstream stations around Porto Velho, but showed no difference between 1997 and 2002. Changes in pH and TSS were observed between 1997 and 2002 (Figure 2). The $\mathrm{pH}$, although remaining constant along the entire stretch of river sampled, showed slightly acidic values (5.9 to 6.6) in 1997 and nearly neutral (6.6 to 6.9) ones in 2002. This difference in the $\mathrm{pH}$ may be related to the erosion of agriculture soils, as well as to the higher transport of suspended particles to the river.

The most important difference in the water properties observed between the two cruises, however, was a 2 to 3 fold increase in total suspended sediments (TSS) concentrations, in particular in the stations receiving major tributaries from the southern portion of Rondônia State (stations 4 to 13) where major differences in the $\mathrm{pH}$
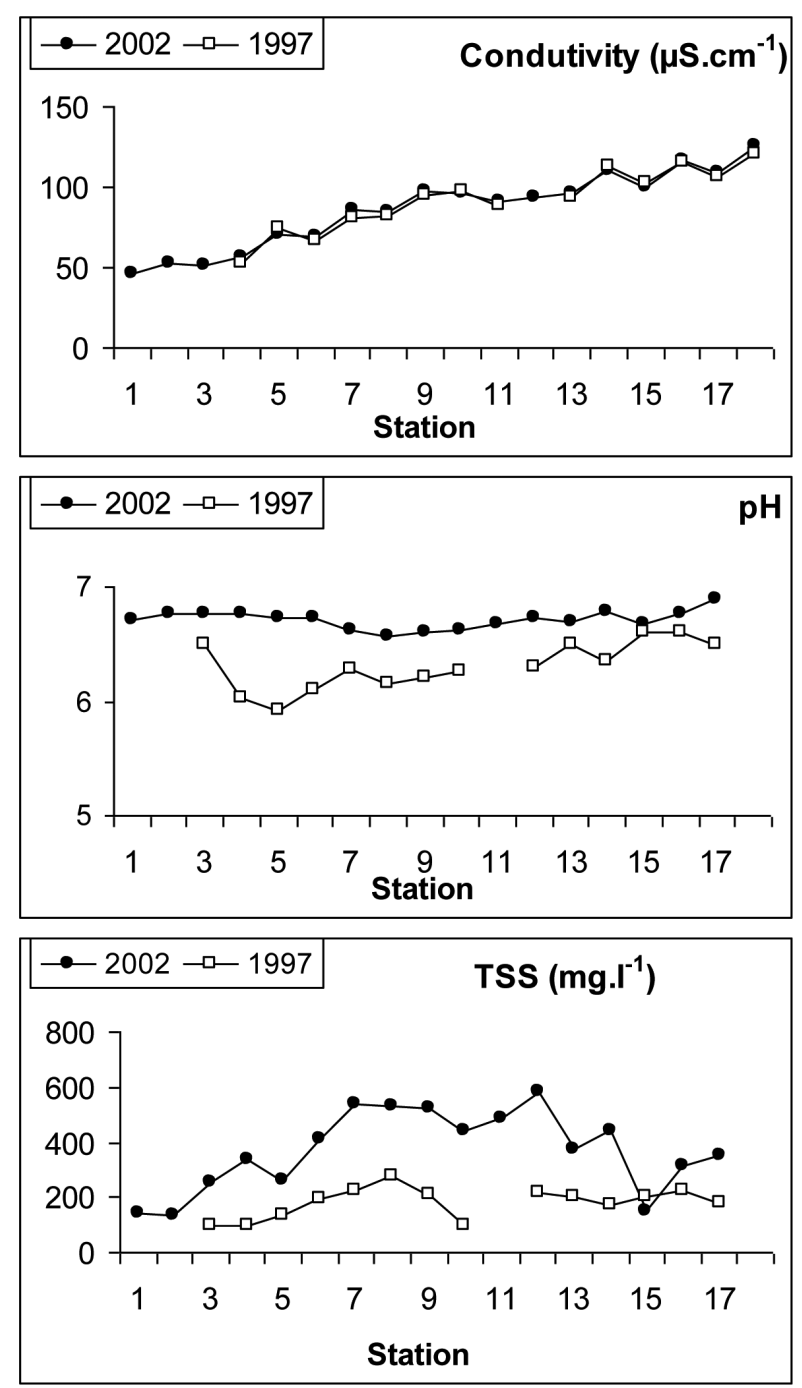

Figure 2. Hydrochemistry of the Madeira River from Porto Velho (stations 15 to 18), the middle section (14 to 5) to the confluence with the Amazon River (stations 4 to 1).

were also observed between the two cruises. The total suspended solids content in waters between stations 4 and 13 varied from 100 to $274 \mathrm{mg} . \mathrm{l}^{-1}$ in 1997, whereas in 2002 the TSS content between the same stations varied from 148 to $580 \mathrm{mg} \cdot \mathrm{l}^{-1}$.

Figure 3 shows $\mathrm{Hg}$ concentrations in the TSS, and dissolved and particulate $\mathrm{Hg}$ measured in the Madeira River waters in 1997 and 2002. Roughly three sectors can be identified relative to $\mathrm{Hg}$ concentrations distribution: a first sector represented by 4 stations covering the large fan of the Madeira River mouth and the Amazon River 

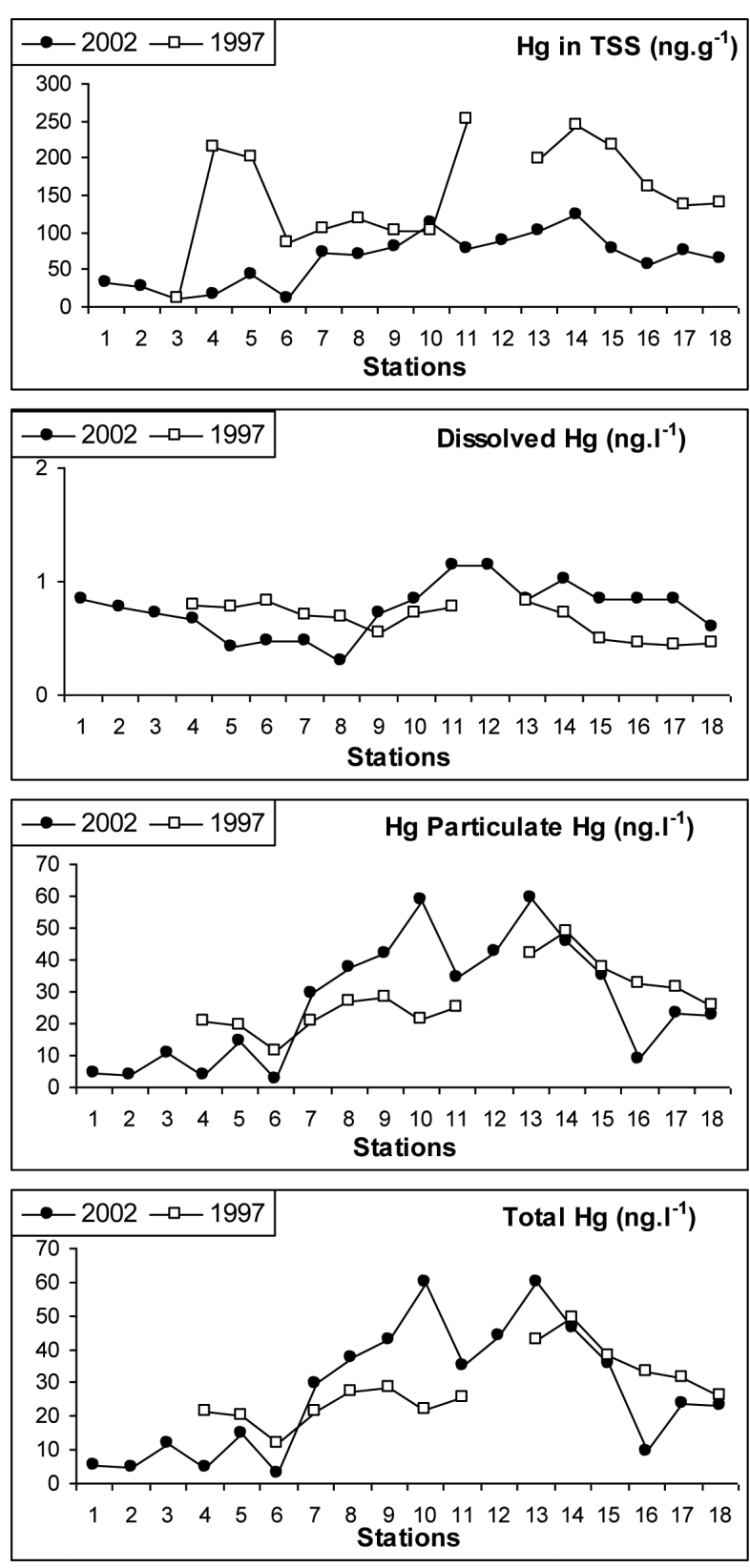

Figure 3. Mercury distribution in suspended matter and waters in the Madeira River from Porto Velho (stations 15 to 18), the middle section (14 to 5) to the confluence with the Amazon River (stations 4 to 1).

just downstream the outflow of the Madeira River, a second sector including those stations (stations 5 thru 14), receiving the outflows of two major tributaries, the Jamari River (including Samuel dam) and the Machado River, both draining the most deforested area of the state converted into pasture and agriculture (Morton et al. 2006), and a third sector represented by the major gold extraction activities in the past closer to Porto Velho (stations 15 thru 18).

The behavior of $\mathrm{Hg}$ among the different fractions was different. Mercury concentrations in the TSS decreased significantly between the two cruises. More significant decreases were observed at the stations surrounding Porto Velho downstream to Humaitá, including stations 18 to 10 , the stations most affected by gold extraction activities in the last two decades of the past century located along the upper Madeira River (Lacerda et al. 1989, Maurice-Bourgoin et al. 2000, Leckler et al. 2000). At these stations, $\mathrm{Hg}$ concentrations in the TSS in 1997 varied from 140 to $250 \mu \mathrm{g} . \mathrm{g}^{-1}$, whereas in 2002 concentrations at the same stations varied from 57 to $122 \mu \mathrm{g} \cdot \mathrm{g}^{-1}$ (Figure 3). The draining area between stations 18 thru 10 also witnessed deforestation rates increasing from about 13,000 km². $\mathrm{yr}^{-1}$ in 1997 to nearly $23,000 \mathrm{~km}^{2} \cdot \mathrm{yr}^{-1}$ in 2002 (INPE 2009). Simultaneously, soy production in this portion of the state increased from 20,000 tons. $\mathrm{yr}^{-1}$ in 1999 to nearly 100,000 tons. $\mathrm{yr}^{-1}$ in 2002. These results suggest that, between the two periods, not only TSS impoverished in $\mathrm{Hg}$ were exported downstream from the previous mining areas, but also larger quantities of suspended matter, also poorer in $\mathrm{Hg}$, were available for river transport due to the forest conversion followed by an increasing soil erosion.

The relative chemical composition of TSS observed in 2002 is presented in Table II. The ratios between $\mathrm{Fe}$, a conservative element that is abundant in most latosols of the basin, and the other trace metals, show a sharp change when comparing the two portions of the Madeira River. The increase in $\mathrm{Fe}$ concentrations relative to other trace metals in the TSS verified downstream station 15 down to station 10 is in agreement with a contribution from the iron rich soils of central Rondônia, extensively ploughed for agriculture (Bonoto and Silveira 2003). This suggests that deforestation and soil erosion are the major sources 
of TSS to the Madeira River in this section, and of a lower $\mathrm{Hg}$ content in the suspended matter observed in 1997 relative to 2002.

Dissolved and particulate $\mathrm{Hg}$ concentrations showed different distribution patterns depending on the portion of the river. At the stations under the influence of, or just downstream from the area of influence of the gold extraction sites, closer to Porto Velho (stations 18 to 15 ), dissolved $\mathrm{Hg}$ was higher in 2002 (0.6 - 0.8 ng..$^{-1}$; average 0.78 ng..$\left.^{-1}\right)$ than in 1997 (0.4-0.5 ng..$^{-1}$; average 0.47 ng..$\left.^{-1}\right)$, whereas particulate $\mathrm{Hg}$ concentrations were lower in $2002\left(8.5-35\right.$; average $\left.=22.3 \mathrm{ng} . \mathrm{l}^{-1}\right)$ than in 1997 (25.4 - 37.5 ng..$^{-1}$; average 31.7 ng..$\left.^{-1}\right)$. From stations 14 to 5 regarding the water samples collected downstream the major area draining central Rondônia, dissolved Hg concentrations in 2002 and 1997 were equal (0.4 - 1.1 ng.1-1; average 0.74 ng.1-1). However, notwithstanding the decrease in the $\mathrm{Hg}$ concentration in the TSS, particulate $\mathrm{Hg}$ species still presented higher values in 2002 (14.5 - 58.8 ng.1-1; average 40.4 ng.1-1) relative to 1997 (11.2 - 48.8 ng.1-1; average 26.9 ng.1-1).

The analysis of these results strongly suggest the increasing TSS in the Madeira River in 2002 as the major responsible for the high $\mathrm{Hg}$ load found in the river water compared to 1997 . In samples from the 2002 cruise, there was a significant positive correlation between total $\mathrm{Hg}$ content and TSS concentrations $(\mathrm{r}=0.874 ; \mathrm{n}=15 ; \mathrm{P}<0.01)$. In 1997, there was no significant correlation between the two variables $(\mathrm{r}=0.433 ; \mathrm{n}=15 ; \mathrm{P}=\mathrm{ns})$, suggesting that a source other than soil erosion, probably the gold extraction activity itself, was the major responsible for the $\mathrm{Hg}$ content in the river waters. Leckler et al. (2000) measured a significant increase in the $\mathrm{Hg}$ content in the water upstream and downstream of operating dredges. This confirms the capacity of gold extraction in increasing instantaneous $\mathrm{Hg}$ concentrations in the Madeira River water. Downstream of these stations, insufficient data do not allow comparisons between 1997 and 2002.

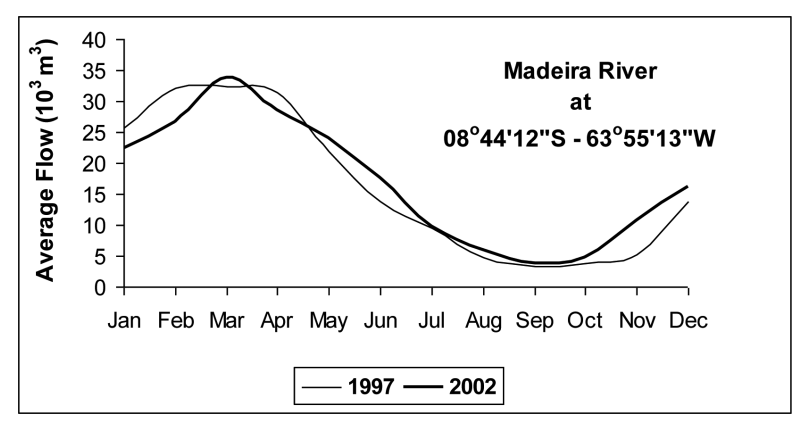

Figure 4. Monthly instantaneous fluxes of water (103m3), estimated for the Madeira River in 1997 and 2002.

Both cruises occurred in May, and a small difference in the monthly average water discharge of only about $20 \%$ was observed between the two years $\left(1997=31,000 \mathrm{~m}^{3} \cdot \mathrm{s}^{-1} ; 2002=23,000 \mathrm{~m}^{3} \cdot \mathrm{s}^{-1}\right)$ (Figure 4).

When estimating instantaneous fluxes of water, sediments and $\mathrm{Hg}$ species, the impact of land use change is even more clear (Figure 5). Instantaneous fluxes were obtained from average values of concentrations from 4 adjacent stations ( 2 downstream and 2 upstream) from the major locations along the Madeira River. The results show that notwithstanding the smaller water discharges verified in 2002 relative to 1997 , most sediment and $\mathrm{Hg}$ fluxes were higher in 2002, in the river sectors receiving the drainage from Humaitá and even more from Manicoré. These are the areas under the stronger impact form deforestation and conversion to husbandry and agriculture. Instantaneous sediment fluxes increased along the entire river, varying from $11 \%$ in Humaitá to $34 \%$ in Porto Velho to $45 \%$ in Manicoré. On the other hand, particulate $\mathrm{Hg}$ fluxes decreased about $60 \%$ around Porto Velho, a probable result of the cessation of the gold extraction activities, but increased $23 \%$ around Manicoré, after the discharge of major tributaries and represent a probable result of forest conversion. Dissolved $\mathrm{Hg}$ fluxes decreased 13\% around Porto Velho, but increased $24 \%$ around Humaitá and remained constant around Manicoré (Figure 5).

Increasing dissolved $\mathrm{Hg}$ fluxes directly enhances $\mathrm{Hg}$ availability to the biota, since dissolved 

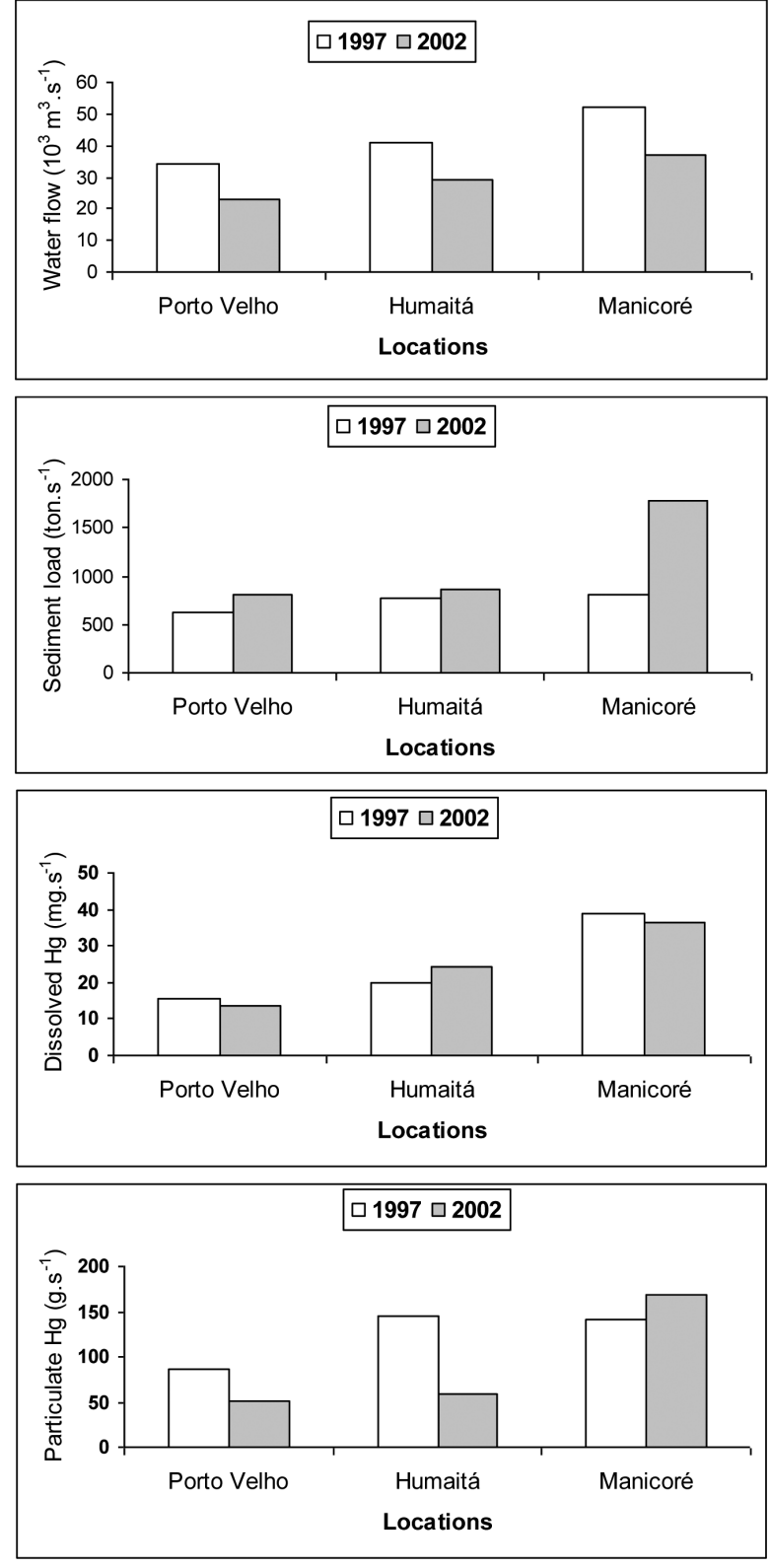

Figure 5. Instantaneous fluxes of water $\left(\mathrm{m}^{3} \cdot \mathrm{s}^{-1}\right)$, suspended solids (tons. $\left.\mathrm{s}^{-1}\right)$ and dissolved $\left(\mathrm{mg} \cdot \mathrm{s}^{-1}\right)$ and particulate $\mathrm{Hg}\left(\mathrm{g} \cdot \mathrm{s}^{-1}\right)$ estimated for three different sectors of the lower madeira River.

$\mathrm{Hg}$ species are ready bio-accumulated. Although particulate $\mathrm{Hg}$ will preferentially be deposited in flooded areas, marginal lakes and artificial reservoirs, increasing particulate $\mathrm{Hg}$ fluxes will also, although delayed in time and space, increase $\mathrm{Hg}$ availability, since these depositional environments favor $\mathrm{Hg}$ transformations, including biomagnification due to slightly acid conditions, organic-rich sediments and intense microbial activity (Palermo et al. 2004a, b, c). Therefore, the increase in total $\mathrm{Hg}$ fluxes due to land use changes observed between 1997 and 2002 will probably be responsible, at least in part, for the maintenance of present relatively high $\mathrm{Hg}$ concentrations found in fish and humans along the Madeira River (Bastos et al. 2006)

\section{CONCLUSION}

The mobilization of $\mathrm{Hg}$ due to land use changes in the Madeira River Basin is most probably responsible for maintaining elevated $\mathrm{Hg}$ levels observed even today in many compartments of the region, in particular in high trophic level fish species and riverine human populations depending on them for their diet. The mobilization occurs through different mechanisms, mostly from erosion and leaching of converted forest soils. The comparison of suspended sediments and of $\mathrm{Hg}$ fluxes between the two periods investigated suggest that the present rate of forest conversion occurring in the Madeira River Basin is already capable of changing sediments and $\mathrm{Hg}$ transport through the river even considering the immense magnitude of fluxes involved. The results presented highlight the necessity of maintaining $\mathrm{Hg}$ monitoring programs in the Amazon region, notwithstanding the cessation of mining activities since internal biogeochemical processes, maximized by land use changes, result in elevated levels of bio-available $\mathrm{Hg}$ in the Madeira River ecosystem.

\section{ACKNOWLEDGMENTS}

This paper is part of the project "Biogeochemistry of Mercury in Tropical Ecosystems" (BMT), financed by Conselho Nacional de Desenvolvimento Científico e Tecnológico (CNPq) through Programa de Apoio a Núcleos de Excelência (PRONEX project, Proc. No. 66.2007/1998-0), and the BIOMERCURY Program supported by the German Ministry of Science and Technology. We specially thank the 
students of the Environmental Biogeochemistry Laboratory, Universidade Federal de Rondônia, for the help with fieldwork and chemical analysis.

\section{RESUMO}

Foram estudadas as alterações na hidroquímica e na distribuição de $\mathrm{Hg}$ em águas do Rio Madeira entre Porto Velho (RO) e a confluência com o Rio Amazonas (AM) em dois cruzeiros realizados em 1997 e 2002 . A condutividade da água foi similar nos dois períodos, porém o $\mathrm{pH}$ foi significativamente maior em 2002, principalmente ao longo da porção média do curso do rio. A concentração do material suspenso total também aumentou de 1997 a 2002, nesta mesma porção do rio, o que é um resultado da conversão de florestas para outros usos, principalmente pastos e agricultura, que foi intensificada no intervalo entre os dois cruzeiros. As concentrações de $\mathrm{Hg}$ dissolvido foram similares ao longo do rio nos dois cruzeiros, mas as concentrações de $\mathrm{Hg}$ particulado aumentaram significativamente ao longo da porção média de seu curso, embora em 2002 a concentração de Hg no material particulado fosse menor que aquela verificada em 1997. Uma vez que o $\mathrm{Hg}$ particulado representou mais de $90 \%$ do total do Hg presente na água, ocorreu um aumento significativo no transporte de $\mathrm{Hg}$ total pelo Rio Madeira. Embora o garimpo de ouro tenha praticamente cessado na região, a remobilização de $\mathrm{Hg}$ pela conversão de solos florestais para ouros usos é responsável pela manutenção de níveis relativamente elevados de $\mathrm{Hg}$ no meio ambiente do Rio Madeira.

Palavras-chave: desmatamento, Mercúrio, hidroquímica, contaminação, Amazônia

\section{REFERENCES}

ALMEIDA MD, LACERDA LD, BASTOS WR AND HERRMANN JC. 2005. Mercury loss from soils following conversion from forest to pasture in Rondônia, Western Amazon, Brazil. Environ Pollut 137: 179-186.

Almeida MD, Marins RV, PARAQUetTi HMM, Bastos WR AND LACERDA LD. 2009. Mercury degassing from forested and open field soils in Rondônia, Western Amazon, Brazil. Chemosphere 77: 60-66.
Amirbahaman A, RuCK P, FERnANDEZ LJ, HaInES TA AND KAHL JS. 2004. The effect of fire on mercury cycling in the soils of forested watersheds: Acadia National Park, Maine, USA. Wat Air Soil Pollut 152: 313-331.

Bastos WR, GOMES JPO, OLIVEIRA RC, AlmeidA R, NASCIMENTO EL, LACERDA LD, Silveira EG AND PFEIFFER WC. 2006. Mercury in the environment and riverside population in the Madeira River Basin, Amazon, Brazil. Sci Tot Environ 368: 344-351.

BoIsCHIO AAP AND HeNSHEL D. 2000. Fish consumption, fish lore, and mercury pollution - Risk communication for the Madeira River people. Environ Res 84: 108-126.

Bonoto MD AND SILVEIRA EG. 2003. Preference rations for mercury and other chemical elements in the Madeira River, Brazil. J South Amer Earth Sci 15: 911-923.

Cordeiro RC, TURCQ B, Ribeiro MG, LACERDA LD, Capitaneo J, Da Silva AO, Sifeddine A ANd TurCQ PM. 2002. Forest fire indicators and mercury deposition in an intense land use change region in the Brazilian Amazon (Alta Floresta, MT). Sci Tot Environ 293: 247-256.

Ferraz SFB, Vettorazzi A, Theobald DM AND BALLESTER MVR. 2005. Landscape dynamics of Amazon deforestation between 1984 and 2002 in central Rondônia, Brazil: assessment and future scenarios. Forest Ecol Manag 204: 67-83.

ForsberG B, GODOY JM, Victoria R AND MARTINELli LA. 1999. Development and erosion in the Brazilian Amazon: A geochronological case study GeoJournal 19: 399-405.

Fostier AH, Forti MC, Guimarães JRD, Melfi AJ, Boulet R, SAnto CME And KRUG FJ. 2000. Mercury fluxes in a natural forested Amazonian catchment (Serra do Navio, Amapá State, Brazil). Sci Tot Environ 260: 201-211.

Godoy JM, Padovani CR, Guimarães JRD, Pereira JCA, VIEIRA LM, CARVALHO ZL AND GALDINO S. 2002. Evaluation of the siltation of River Taquari, Pantanal, Brazil, through $\mathrm{Pb}-210$ geochronology of floodplain lake sediments. J Braz Chem Soc 13: 71-77.

Guyot JL, Jounnneau JM AND WAsson JG. 1999. Characterization of river bed and suspended sediments in the Rio Madeira drainage basin (Bolivian Amazonia). J South Amer Earth Sci 12: 401-410.

Herpin U, Cerri CC, Carvalho mCS, Markert B, ENZWEILER J, Friese K AND Breulmann G. 2002. Biogeochemical dynamics following land use change from forest to pasture in a humid tropical area (Rondônia, Brazil): a multi-element approach by means of XRF-spectroscopy. Sci Tot Environ 286: 97-109.

INPE. 2009. Estimativa do desmatamento na Amazônia. (São José dos Campos: Instituto Nacional de Pesquisas Espaciais, www.inpe.gov.br) 
LACERDA LD. 2003. Updating global mercury emissions from small-scale gold mining and assessing its environmental impacts. Environ Geol 43: 308-314.

LACERDA LD, PfEIFFER WC, Silveira EG and OtT AT. 1989. Mercury emissions to the Madeira River, Amazon. Biotropica 21: 91-93.

LACERDA LD, SOUZA M and Ribeiro MG. 2004. The effects of land use change on mercury distribution in soils of Alta Floresta, Southern Amazon. Environ Pollut 129: 247-255.

Leckler PJ, Miller JR, LAcerda LD, Vinson D, BONZONGO JC, LYONS WB AND WARWICK JJ. 2000. Elevated mercury concentrations in soils, sediments, water and fish of the Madeira River Basin, Brazilian Amazon: a function of natural enrichments? Sci Tot Environ 260: 87-96.

LODENIUS M, SEPPÄNEN A AND AUTIO S. 1987. Leaching of mercury from peat soil. Chemosphere 16: 1215-1220.

MAgARELli G AND Fostier AH. 2005. Influence of deforestation on the mercury air/soil exchange in the Negro River Basin, Amazon. Atmos Environ 39: 7518-7528.

Marins RV, Paraquetti HHM AND Ayres GA. 2002. Analytical alternative for the physical-chemical speciation of mercury in tropical coastal waters. Quim Nov 25: 372-378.

MAurice-Bourgoin L, Quiroga I, Chincheros J AND COURAU P. 2000. Mercury distribution in waters and fishes of the upper Madeira River and mercury exposure in riparian Amazonian populations. Sci Tot Environ 260: 73-86.

Moraes JFL, Volkoff B, Cerri CC And Bernoux M. 1996. Soil properties under Amazon forest and changes due to pasture installation in Rondonia, Brazil. Geoderma 70: 63-81.

Mortatti J, Ferreira JR, MARTINELli LA, Victoria RL AND TANCREDI ACF. 1989. Biogeochemistry of the Madeira River Basin. GeoJournal 19: 391-397.
Morton DC, Defries RS, Shimabukuro Ye, ANDERson LO, ARAI E, ESPIRITO-SANTO FD, Freitas R AND Morisette J. 2006. Cropland expansion changes deforestation dynamics in the southern Brazilian Amazon. Proc Nat Acad Sci 103: 14637-14641.

Palermo EFA, Kasper D, Reis TS, Nogueira S, Branco CWC AND MALM O. 2004a. Mercury level increase in fish tissues downstream the Tucuruí reservoir, Brazil. RMZ. Mat Geoenviron 51: 1292-1294.

Palermo EFA, Kehrig HA, Branco CWC and Malm O. 2004c. Mercury and methylmercury in suspended particulate matter and sediments of a slightly impacted reservoir of Brazil. RMZ. Mat Geoenviron 51: 1289-1291.

PAlermo EFA, Kehrig HA AND MALm O. 2004b. Inorganic and methyl mercury in food chain from a Brazilian reservoir. RMZ. Mat Geoenviron 51: 1103-1106.

PFFeIFER WC AND LACERDA LD. 1988. Mercury inputs to the Amazon region, Brazil. Environ Technol Lett 9: 325-330.

Roulet M, Lucotte M, CANuel R, FArella $\mathrm{N}$, Courcelles M, Guimarães JRD, Mergler D and AMORIM M. 2000. Increase in mercury contamination recorded in lacustrine sediments following deforestation in the central Amazon. Chem Geol 165: 243-266.

Roulet M, Lucotte M, FARella N, Serique G, Coelho H, Passos CJS, Da Silva ED, De Andrade PS, Mergler D, Guimarães JRD AND AMORIM M. 1999. Effects of recent human colonization on the presence of mercury in Amazonian ecosystems. Wat Air Soil Pollut 112: $297-313$

SCHLÜLER K. 1997. Sorption of inorganic mercury and monomethyl mercury in na iron-humus podzol soil of southern Norway studied by batch experiments. Environ Geol 30: 266-279.

Silveira EG, Bastos WR, Malm O AND Bonoto DM. 2000. The presence of mercury in bottom sediments and rocks from the Madeira River, Brazil. Geociências 19: 283-289. 